\title{
Antihypertensive Treatment with Candesartan Monotherapy Does Not Improve the Quality of Life of Finnish Hypertensive Patients
}

\author{
Juha Varis*, Maarit Ruuska, Jarno Johansson and Ilkka Kantola \\ Department of Medicine, Turku University Hospital, FI-20520 Turku, Finland
}

\begin{abstract}
Candesartan is an effective and widely used antihypertensive medication. The effect of candesartan alone or combined with hydrochlorothiazide and felodipine on the quality of life (QOL) of Finnish hypertensive patients was examined.

Antihypertensive treatment was started and conducted according to protocol by candesartan $8 \mathrm{mg}$ once daily and then increased to $16 \mathrm{mg}$ once daily, if needed. Thereafter, hydrochlorothiazide $12.5 \mathrm{mg}$ or $25 \mathrm{mg}$ once daily and felodipine 5 $\mathrm{mg}$ once daily were added, if needed. QOL was measured using the SF-36 questionnaire at baseline and at 6, 12, 18 and 24 (end of study) weeks. The blood pressure target was a diastolic BP below or equal to $80 \mathrm{mmHg}$.

Ninety-eight hypertensive patients, 42 men and 56 women were studied. The only statistically significant change in QOL was a reduction in QOL among the patients on candesartan monotherapy throughout the study. Their physical functioning, total physical and mental health and total SF-36 score decreased significantly. Non-significant increases in QOL were recorded among patients who had a reduction in their systolic blood pressure, who were older and who had a high systolic blood pressure in the beginning of the study.
\end{abstract}

This study suggests that an adequate antihypertensive effect is an important predictor of QOL for patients being treated for high blood pressure. Candesartan alone without an adequate blood pressure decrease does not improve QOL.

Keywords: Hypertension, candesartan, quality of life, antihypertensive treatment.

\section{INTRODUCTION}

Quality of life [QOL] is a person's subjective experience of overall well-being and functionality. QOL is very difficult to measure objectively, but the last decades has witnessed an increasing interest in the impact of medical treatments and procedures on QOL and this has stimulated the development of various methods to measure QOL. The SF-36 Health Survey was developed in association with the Medical Outcome Study in 1980, translated into Finnish with some modifications and introduced in 1993 [1, 2]. The SF-36 Health Survey is a reliable, easy and versatile way of assessing the QOL of Finnish patients [2, 3]

Treatment compliance is a key factor for successful hypertensive care. Non-compliance is a growing concern, as modern guidelines recommend tight blood pressure (BP) targets which require complex combination therapies and introduction of antihypertensive medication in apparently healthy, who frequently are reluctant to treatment. Thus, proper antihypertensive medication is essential and should be simple, effective and safe. Candesartan, an angiotensin receptor blocker (ARB), is a modern antihypertensive drug and reduces effectively BP compared to various other medications $[4,5]$. As the number of different antihypertensive preparations and of tablets to be taken daily increases, risk of adverse effects rises and this may hamper

*Address correspondence to this author at the Department of Medicine, Turku University Hospital, FI-20520 Turku, Finland; Tel: +358 2 3130657; Fax: +358 2 236132030; E-mail: juha.varis@tyks.fi the gained antihypertensive effect. Angiotensin receptor antagonists and ACE inhibitors, however, have a low incidence of adverse effects and thus compliance should be good [6]. Monotherapy with an ARB might therefore be a candidate for an ideal antihypertensive medication. In this study we used the SF-36 survey to assess the effect of increasing doses of candesartan, with hydrochlorothiazide and felodipine if needed, on QOL and blood pressure.

\section{PATIENTS, MATERIALS AND METHODS}

This study was a part of a blinded, randomised, controlled clinical trial which was planned to compare home BP measurement with ambulatory BP measurement in directing antihypertensive treatment [7]. The study took place in the outpatient clinic of the Turku University Hospital. The protocol was approved by the Ethics Committee of the University of Turku, Finland. The study was conducted according to the Declaration of Helsinki and written informed consent was obtained from all patients.

The study patients were 40-80 years old Finnish patients with essential hypertension. Patients with recent myocardial infarctation, cerebrovascular disease, massive obsesity or pregnancy were excluded.

After pre-entry screening, previous antihypertensive medication was discontinued and the patients underwent a four-week placebo washout period. During the pre-entry period the patients measured their blood pressure daily with a home monitor to obtain a baseline BP estimate. At the end of the four-week wash-out period a 24-hour ambulatory 
blood pressure (ABPM) measurement was performed on all patients.

The patients were recruited among hypertensive patients visiting the Pulssi Medical Center, Turku, Finland or the outpatient clinic of the Department of Medicine in Turku University Hospital, Turku, Finland. Altogether 110 patients who met the inclusion criteria and had no cause for exclusion were included in the study and were randomly allocated to be treated as dictated by home BP-measurements or by ABPM.

After randomization, follow-up visits were scheduled at 6, 12, 18 and 24 weeks. All patients measured their home BP during the week preceding the follow-up visit. Home recordings were made with the patients supine after 15 minutes rest. The patients were advised to avoid coffee or energy drinks in an effort to eliminate factors that might increase or reduce the BP fortuitously. ABPM was also performed on all patients one day before the follow-up visit. The treating physician was blinded to randomization and received only the BP values for the method of measurement into which the patient was randomized, but was not told which method was used to obtain the BP values. All patients were treated by a single physician (IK). The target pressure for both study groups was a diastolic BP $\leq 80 \mathrm{mmHg}$. To achieve this goal, a standardized stepped-care antihypertensive drug regimen was used. After randomization, all patients began therapy with candesartan, $8 \mathrm{mg}$ once daily (step 1). If the mean diastolic pressure at subsequent visits was above the target pressure $(>80 \mathrm{mmHg})$, the treatment was intensified stepwise to candesartan $16 \mathrm{mg}$ once daily (step 2), candesartan $16 \mathrm{mg}$ once daily + hydrochlorothiazide $12.5 \mathrm{mg} / 25 \mathrm{mg}$ once daily (step 3) and candesartan $16 \mathrm{mg}$ once daily + hydrochlorothiazide $12.5 \mathrm{mg} / 25 \mathrm{mg}$ once daily + felodipine $5 \mathrm{mg}$ once daily (step 4) (Table 1). The previous treatment schedule was continued if the BP was below target pressure and the patient was symptom-free and the dose or was reduced, if the patient had symptoms of hypotension.

Quality of life was assessed by using the SF-36 questionnaire during all visits. The patients filled in the questionnaire during their visit in the outpatient clinics. Total physical health was defined as the mean of physical functioning, role physical, bodily pain, general health, vitality and social functioning. Total mental health was defined as the mean of bodily pain, general health, vitality, social functioning, emotional role and mental health. The total SF-36 score was the mean of all eight parameters. All parameters were scored from 0 to 100 .

\section{Statistical Analysis}

Continuous variables are expressed as mean (standard deviation, SD). Database management and statistical analysis were performed using the SPSS software, version 17.0. The significance of group differences of continuous variables was assessed with the unpaired Student's $t$ test or one way analysis of variance, as appropriate. The $\chi^{2}$-test was used for comparing two proportions. The cut-off level for statistical significance was set at P-value $<0.05$. Normality of the distribution of the continuous variables were assessed with the Shapiro-Wilks test. A repeated-measures general linear method was used to evaluate the within-group changes of blood pressure and SF-36-measured quality of life. Correlations between variables were determined by Pearson's correlation analysis. Multivariate stepwise linear regression analysis was applied to assess independent predictors of the variables of interest, whenever the univariate $p$-value was $<0.05$.

\section{RESULTS}

Altogether 110 patients were recruited in the study. Twelve patients were excluded because of incomplete SF-36 questionnaires. Twenty-four patients had used out-of protocol medication at the end of the study. Altogether 98 patients were analyzed.

The mean age of the patients was 54.5 (7.7) years. Fortytwo $(43 \%)$ were male and $56(57 \%)$ female. The mean daytime ambulatory BP after the four week placebo period was $147.1(12.1) / 94.0(6.4) \mathrm{mmHg}(\mathrm{n}=98)$. Candesartan $8 \mathrm{mg}$ once daily $(\mathrm{n}=78)$ decreased the daytime ambulatory systolic BP by 10.0 (8.7) $\mathrm{mmHg}$ and the diastolic BP by 6.7 (6.1) $\mathrm{mmHg}$; when the dose was increased to $16 \mathrm{mg}$ once daily $(n=50)$ an additional decrease in the blood pressure of 4.9 (8.8)/3.2 (5.4) $\mathrm{mmHg}$ was recorded. Combining hydrochlorothiazide $12.5 \mathrm{mg}$ or $25 \mathrm{mg}$ once daily to candesartan $16 \mathrm{mg}$ once daily $(\mathrm{n}=34)$ decreased the BP by $5.9(8.8) / 3.6$ (5.5) $\mathrm{mmHg}$ further. At the end of the study $40 / 98(41 \%)$ patients reached an ambulatory diastolic daytime BP $\leq 80$ $\mathrm{mmHg}$ and 69/98 (70.4\%) $\leq 85 \mathrm{mmHg}$ (Table 2).

The SF-36 scores were calculated and plotted on a scale from 0 (poorest) to 100 (best). The results are given in Tables 3 and 4. Physical functioning, total physical health, mental health and the total SF-36 score decreased significantly among the patients using candesartan $8 \mathrm{mg}$ or $16 \mathrm{mg}$ monotherapy at the end of the study compared to their scores during the placebo phase (general linear method,

Table 1. Study Protocol

\begin{tabular}{|c|c|c|c|}
\hline & Week & Procedure* & Antihypertensive Treatment \\
\hline \hline Base-line visit & -2 & Physical examination & Previous medication stopped, placebo initiated \\
\hline First visit & 0 & Office BP measurement & $8 \mathrm{mg}$ candesartan started \\
\hline Second visit & 6 & Office BP measurement & If diastolic pressure $>80$ dose increasing regimen* adopted \\
\hline Third visit & 12 & Office BP measurement & If diastolic pressure $>80$ dose increasing regimen** adopted \\
\hline Fourth visit & 18 & Office BP measurement & If diastolic pressure $>80$ dose increasing regimen** adopted \\
\hline Final visit & 24 & Office BP measurement & Ordinary antihypertensive treatment started \\
\hline
\end{tabular}

*24h ambulatory BP measurement; home blood pressure measurement (HBPM); SF questionnaire filled before each visit

$* *=$ Candesartan dose doubled to $16 \mathrm{mg}$ od then add-on hydrochlorothiazide $(12.5 \mathrm{mg}$ or $25 \mathrm{mg})$ and thereafter felodipine $5 \mathrm{mg}$ od

The patient was randomized at the first visit either to treatment according to HBPM or $24 \mathrm{~h}$ ambulatory measurement. 
Table 2. Mean Systolic and Diastolic 24h Blood Pressure in Different Phases of the Study by Treatment. Only Patients on 8 mg of Candesartan During the First Visit were Included in the Placebo Phase. HCTZ=Hydrochlorothiazide Either 12.5 or 25 mg

\begin{tabular}{|c|c|c|c|}
\hline & Mean (SD) Systolic 24h Pressure & Mean (SD) Diastolic 24h Pressure & Number of Patients \\
\hline \hline Placebo & $144.5(11.3)$ & $91.6(6.5)$ & 78 \\
\hline 8 mg candesartan & $134.2(11.5)$ & $84.5(6.8)$ & 78 \\
\hline 16 mg candesartan & $132.8(11.0)$ & $83.7(6.8)$ & 50 \\
\hline 16 mg candesartan + HCTZ & $128.6(9.9)$ & $82.2(6.6)$ & 34 \\
\hline
\end{tabular}

Table 3). The change in physical functioning correlated with the HDL-cholesterol concentration $(\mathrm{r}=-0.527, \mathrm{p}=0.010)$, with the change in systolic $(\mathrm{r}=0.50, \mathrm{p}=0.016)$ and diastolic $(\mathrm{r}=0.45, \mathrm{p}=0.030)$ home blood pressure, with the change in 24 hour ABPM systolic BP $(r=0.43, p=0.042)$ and systolic $\mathrm{BP}$ in the beginning of the study $(\mathrm{r}=0.43, \mathrm{p}=0.039)$. In the linear stepwise regression model HDL-cholesterol was a predictive factor $(\mathrm{p}=0.002)$. The change in total physical health correlated with age $(\mathrm{r}=0.41, \mathrm{p}=0.048)$, with fasting blood glucose $(r=0.42, p=0.041)$, with the change in 24 hour ABPM systolic BP $(r=0.49, p=0.015)$ and with the change in nocturnal ambulatory systolic $\mathrm{BP}(\mathrm{r}=0.51, \mathrm{p}=0.011)$. Here, age was a predictive factor $(\mathrm{p}=0.008)$. The change in total mental health correlated only with age $(\mathrm{r}=0.42, \mathrm{p}=0.040)$. The change in the total SF-36 score correlated with the HDL-cholesterol concentration in the beginning of the study $(\mathrm{r}=-0.44, \mathrm{p}=0.033)$, with the change in 24 hour ABPM systolic blood pressure $(r=0.430, p=0.036)$ and with the change in nocturnal ambulatory systolic blood pressure $(\mathrm{r}=0.46, \mathrm{p}=0.023)$. HDL-cholesterol $(\mathrm{p}=0.001)$ and age $(p=0.013)$ were predictive factors were.

In contrast, physical functioning increased significantly toward the end of the study compared to the placebo phase among the patients who used the combination of candesartan and hydrochlorothiazide (Table 3). Physical functioning was also significantly better among the patients who took the candesartan-hydrochlorothiazide combination compared to those who took using candesartan monotherapy (93.6 (9.3) vs 86.3 (13.5), $\mathrm{p}=0.04)$. There was no significant change in the other SF-36 parameters between patients using one, two or three antihypertensive drugs at the end of the study (data not shown). If felodipine was added to the regimen emotional and mental health and total SF-36 score increased significantly compared to placebo at the end of the study,

If the comparison between active drug and placebo was made by a general linear regression method at different medication phases (visits 12,18 and 24 weeks $(n=65-69)$ ) there were only a few significant changes (Table 4).

In all patients, regardless of medication, the change in total physical health and total SF-36 score during 28 weeks correlated primarily with age and systolic blood pressure, not with diastolic blood pressure (Table 5). Physical functioning correlated with age and most of the blood pressure parameters. There were no correlations between, on the one hand, the SF-36 mental parameters and, on the other hand, demographics and blood pressure parameters (data not shown). By linear stepwise regression analysis total physical health was predicted by age $(\mathrm{p}=0.01)$, total SF-36 by 24 hour ambulatory systolic BP change $(\mathrm{p}=0.004)$, physical functioning by 24 hour ambulatory systolic BP change $(p=0.0001)$, role physical by 24 hour ambulatory systolic BP change $(p=0.017)$ and general health by age $(p=0.005)$ and by 24 hour ambulatory systolic BP change $(\mathrm{p}=0.029)$.

Table 3. Changes in Parameters of the SF-36 Questionnaire: 28 Weeks Compared to the Placebo Phase by Specified Medication at the End of the Study. General Linear Method, Measurements at 0, 6,12,18 and 24 Weeks. Statistically Significant Changes are Bolded

\begin{tabular}{|c|c|c|c|c|c|c|c|c|c|c|c|}
\hline Comparison & $\begin{array}{c}\text { Physical } \\
\text { Functioning }\end{array}$ & $\begin{array}{c}\text { Role- } \\
\text { Physical }\end{array}$ & $\begin{array}{c}\text { Bodily } \\
\text { Pain }\end{array}$ & $\begin{array}{l}\text { General } \\
\text { Health }\end{array}$ & $\begin{array}{c}\text { Total } \\
\text { Physical } \\
\text { Health }\end{array}$ & Vitality & $\begin{array}{c}\text { Social } \\
\text { Functioning }\end{array}$ & $\begin{array}{c}\text { Role- } \\
\text { Emotional }\end{array}$ & $\begin{array}{l}\text { Mental } \\
\text { Health }\end{array}$ & $\begin{array}{c}\text { Total } \\
\text { Mental } \\
\text { Health }\end{array}$ & $\begin{array}{l}\text { Total } \\
\text { SF-36 }\end{array}$ \\
\hline \multirow{2}{*}{ 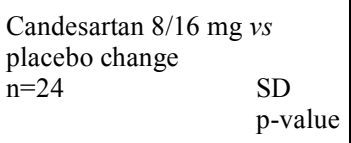 } & -7.8 & -9.4 & -5.7 & -7.0 & -5.9 & -5.4 & 0 & -8.4 & -0.2 & -4.4 & -5.7 \\
\hline & $\begin{array}{c}16.4 \\
\mathbf{0 . 0 0 2}\end{array}$ & $\begin{array}{c}36.0 \\
0.525\end{array}$ & $\begin{array}{c}27.4 \\
0.509\end{array}$ & $\begin{array}{c}26.9 \\
0.197\end{array}$ & $\begin{array}{c}16.4 \\
\mathbf{0 . 0 5 5}\end{array}$ & $\begin{array}{c}22.4 \\
0.125\end{array}$ & $\begin{array}{c}19.2 \\
0.708\end{array}$ & $\begin{array}{c}28.2 \\
0.246\end{array}$ & $\begin{array}{c}13.7 \\
0.048\end{array}$ & $\begin{array}{l}13.9 \\
0.063\end{array}$ & $\begin{array}{c}15.4 \\
\mathbf{0 . 0 3 4}\end{array}$ \\
\hline \multirow{2}{*}{$\begin{array}{ll}\mathrm{CA}^{*}+\mathrm{HCTZ}^{* *} \text { vs } \text { placebo } \\
\text { change } \\
\mathrm{n}=23 & \mathrm{SD} \\
& \text { p-value }\end{array}$} & +3.4 & 0 & -2.4 & -0.4 & -2.6 & -5.4 & -4.9 & -2.9 & -1.0 & -2.9 & +0.5 \\
\hline & $\begin{array}{c}28.1 \\
\mathbf{0 . 0 4 4}\end{array}$ & $\begin{array}{c}45.9 \\
0.663\end{array}$ & $\begin{array}{c}35.3 \\
0.974\end{array}$ & $\begin{array}{c}22.7 \\
0.569\end{array}$ & $\begin{array}{c}24.2 \\
0.636\end{array}$ & $\begin{array}{c}28.5 \\
0.145\end{array}$ & $\begin{array}{c}28.6 \\
0.786\end{array}$ & $\begin{array}{c}21.9 \\
0.925\end{array}$ & $\begin{array}{c}21.9 \\
0.619\end{array}$ & $\begin{array}{c}24.3 \\
0.761\end{array}$ & $\begin{array}{c}31.6 \\
0.888\end{array}$ \\
\hline $\begin{array}{ll}\mathrm{CA}^{*}+\mathrm{HCTZ}^{*} *+\text { felodipine } \\
5 \mathrm{mg} \text { vs placebo } & \text { change } \\
\mathrm{n}=18 & \mathrm{SD} \\
& \text { p-value }\end{array}$ & $\begin{array}{c}-0.9 \\
28.5 \\
0.106\end{array}$ & $\begin{array}{c}+4.4 \\
55.3 \\
0.308\end{array}$ & $\begin{array}{c}+4.7 \\
34.7 \\
0.354\end{array}$ & $\begin{array}{c}-1.6 \\
32.6 \\
0.654\end{array}$ & $\begin{array}{c}+1.7 \\
31.9 \\
0.146\end{array}$ & $\begin{array}{c}-2.9 \\
30.8 \\
0.111\end{array}$ & $\begin{array}{c}+0.7 \\
32.3 \\
0.122\end{array}$ & $\begin{array}{c}+13.7 \\
51.4 \\
\mathbf{0 . 0 2 6}\end{array}$ & $\begin{array}{c}+1.6 \\
26.5 \\
\mathbf{0 . 0 4 4}\end{array}$ & $\begin{array}{l}+3.7 \\
31.5 \\
0.115\end{array}$ & $\begin{array}{c}+3.2 \\
32.2 \\
\mathbf{0 . 0 4 2}\end{array}$ \\
\hline
\end{tabular}


Table 4. Changes in Different Parameters of the SF-36 Questionnaire Compared to the Placebo Phase. The Patients who Used the Specified Medication at the Visits Three (Week 12), Four (Week 18) and Five (Week 24). General Linear Method, Measurements at 0, 6, 12, 18 and 24 Weeks. Statistically Significant Changes are Bolded

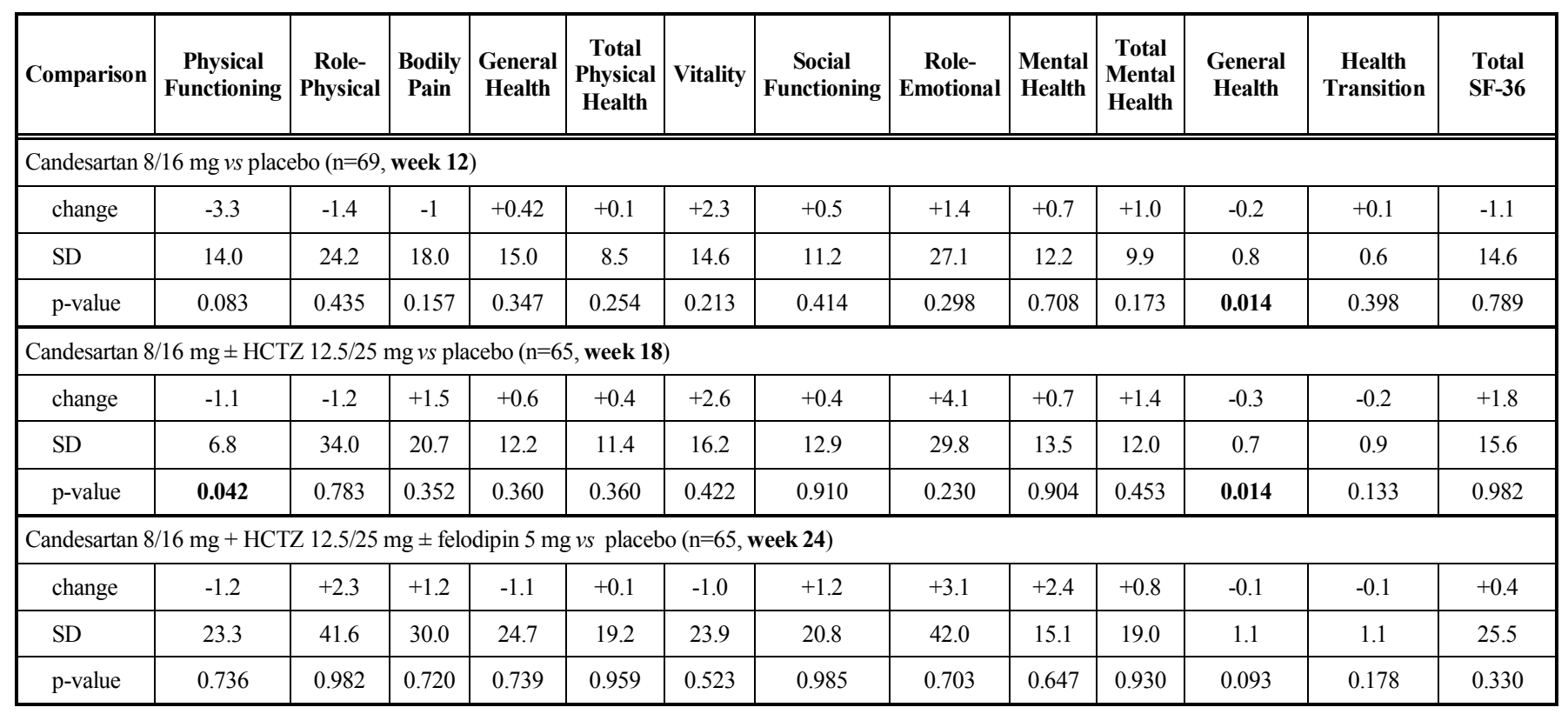

\section{DISCUSSION}

At the outset, the patients were clearly hypertensive as defined by the hypertension treatment guidelines. Adequate blood pressure control in accordance with the goals of the guidelines was achieved by the antihypertensive medication [8]. As expected, the change in blood pressure was most prominent in the beginning of the study, i.e., after introduction of $8 \mathrm{mg}$ of candesartan once daily [5]. Both the systolic and the diastolic blood pressure sank as medication was intensified, but not as much as when the antihypertensive medication was introduced. Because sufficient antihypertensive control was achieved, any changes in QOL were mostly predicted by the change in blood pressure, especially the change in systolic blood pressure. Candesartan alone did not increase the quality of life of the patients, probably because the blood pressure change was not very marked. Our study suffers from relatively small sample size, a short observation period and lack of controls. However, since the Finnish population is quite homogenous we postulate that despite the listed shortcomings reliable conclusions can be drawn.

The physical functioning of our patients on candesartan monotherapy throughout the study decreased compared to the placebo period and was inferior to the patients who used the candesartan-hydrochlorothiazide combination. Also the total SF-36 score decreased significantly but there was no significant difference compared to the patients using combination therapy at the end of the study. Worsening of physical functioning occurred preferentially in patients whose systolic blood pressure decreased the least, in young patients and in patients whose systolic blood pressure was not very high in the beginning of the study. In the group of patients on triple combination treatment at the end of the study, mental health and the total SF-36 score increased significantly compared to placebo period.
Compared to the placebo period, the changes at the end of the individual medication phases (at 12, 18 and 24 weeks) exhibited no significant trends in the separate SF-36 parameters. In all patients, young age and low systolic blood pressure in the beginning of the study correlated with a small increase or worsening of the total physical health and total SF-36 scores. A large decrease in the systolic blood pressure correlated with an increase in total physical health and the total SF-36 score. The mental parameters of the SF-36 questionnaire did not correlate with any of the demographic or blood pressure parameters.

Patients with high blood pressure have reported inferior QOL compared to normotensive patients [9]. The time since start of antihypertensive therapy, organ damage or systolic/diastolic blood pressure level are inversely associated with QOL $[9,10]$ and blood pressure reduction improves QOL [11]. It is not known if improved QOL is due to the benefits of blood pressure reduction per se or to the psychological effects of patients witnessing lower blood pressure readings [11,12]. The adverse effects of antihypertensive drugs may also weaken QOL. Nonpharmaceutical treatment of blood pressure does not affect QOL adversely [13].

Different hypertension treatment studies are difficult to compare because of variable inclusion criteria and QOL assessment [14]. A review by Bremner (2002) concluded that no antihypertensive treatment had been shown conclusively to improve QOL [14]. Males and females and different ethnic groups may respond differently to antihypertensive therapy.

Lambert et al. (2012) demonstrated that nonpharmaceutical BP treatment using radio frequency renal denervation improvement slightly selected SF-36 parameters but the changes had no direct association with the magnitude of $\mathrm{BP}$ reduction [15]. This observation is interesting and raises doubt as to whether lowering $\mathrm{BP}$ is essential for better 
Table 5. Correlations Between the Changes in the SF-36 Scores During 28 Weeks and Demographic and Blood Pressure Parameters in All Patients $(\mathbf{n}=\mathbf{9 8})$. Statistically Significant Correlations are Bolded

\begin{tabular}{|c|c|c|c|c|c|c|c|c|c|c|c|c|c|}
\hline & 总 & 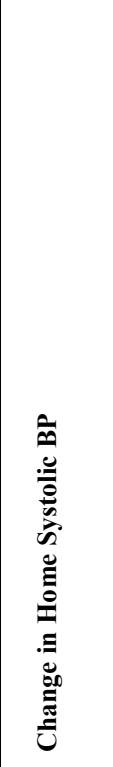 & 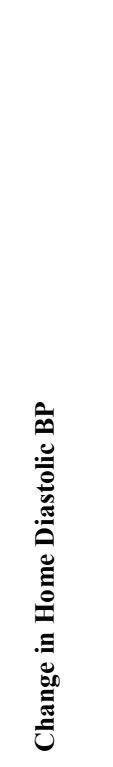 & 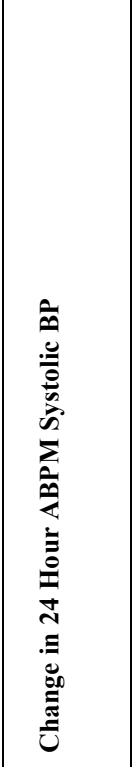 & 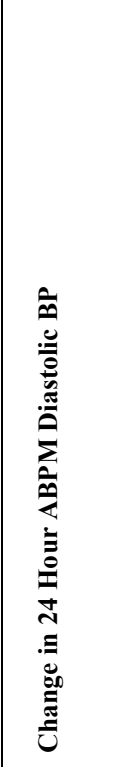 & 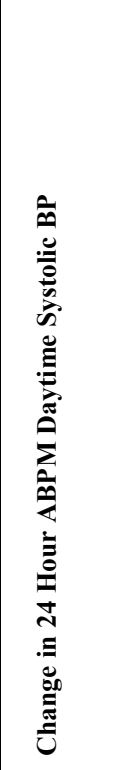 & 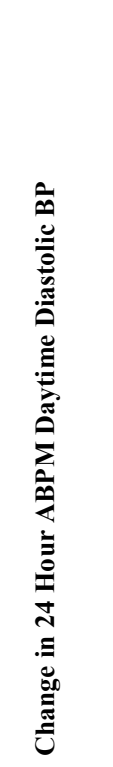 & 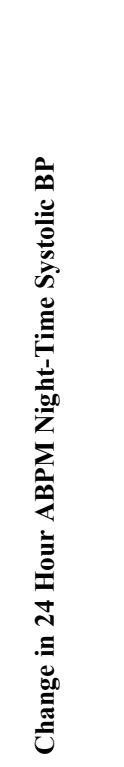 & 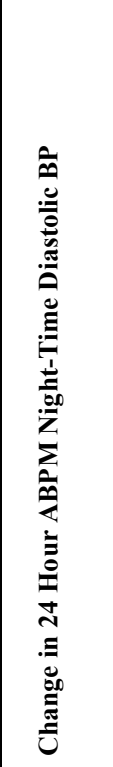 & 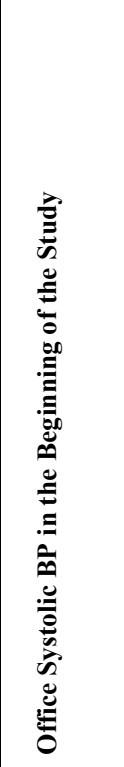 & 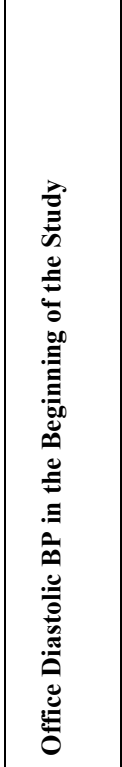 & 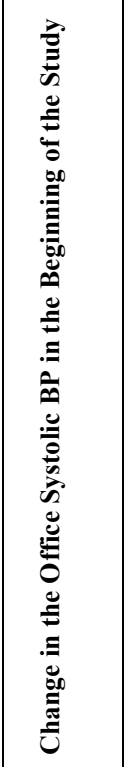 & 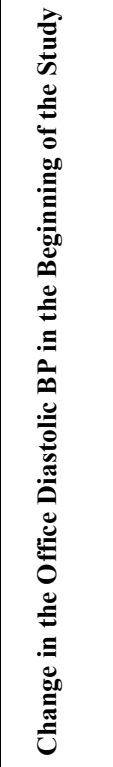 \\
\hline $\begin{array}{l}\text { Physical } \\
\text { functioning }\end{array}$ & $\begin{array}{l}r=0.268 \\
p=0.012\end{array}$ & $\begin{array}{l}r=0.358 \\
p=0.001\end{array}$ & $\begin{array}{l}r=0.218 \\
p=0.040\end{array}$ & $\begin{array}{c}r=0.412 \\
p=0.0001\end{array}$ & $\begin{array}{l}r=0.231 \\
p=0.029\end{array}$ & $\begin{array}{c}r=0.395 \\
p=0.0001\end{array}$ & $\begin{array}{l}r=0.198 \\
p=0.063\end{array}$ & $\begin{array}{c}r=0.366 \\
p=0.0001\end{array}$ & $\begin{array}{l}r=0.234 \\
p=0.027\end{array}$ & $\begin{array}{l}r=-0.311 \\
p=0.003\end{array}$ & $\begin{array}{l}r=-0.142 \\
p=0.185\end{array}$ & $\begin{array}{l}r=-0.266 \\
p=0.011\end{array}$ & $\begin{array}{l}\mathrm{r}=-0.149 \\
\mathrm{p}=0.163\end{array}$ \\
\hline Role $\mathrm{p}$ & $\begin{array}{l}r=0.217 \\
p=0.043\end{array}$ & $\begin{array}{l}r=0.158 \\
p=0.139\end{array}$ & $\begin{array}{l}r=0.029 \\
p=0.790\end{array}$ & $\begin{array}{l}\mathbf{r}=\mathbf{0 . 2 5 7} \\
\mathbf{p}=\mathbf{0 . 0 1 5}\end{array}$ & $\begin{array}{l}r=0.069 \\
p=0.518\end{array}$ & $\begin{array}{l}r=0.221 \\
p=0.037\end{array}$ & $\begin{array}{l}r=0.025 \\
p=0.814\end{array}$ & $\begin{array}{l}\mathrm{r}=0.180 \\
\mathrm{p}=0.092\end{array}$ & $\begin{array}{l}r=0.030 \\
p=0.779\end{array}$ & $\begin{array}{l}r=-0.254 \\
p=0.016\end{array}$ & $\begin{array}{l}r=-0.086 \\
p=0.420\end{array}$ & $\begin{array}{l}r=-0.054 \\
p=0.616\end{array}$ & $\begin{array}{l}r=-0.054 \\
p=0.616\end{array}$ \\
\hline Bodily pain & $\begin{array}{l}r=0.163 \\
p=0.130\end{array}$ & $\begin{array}{l}r=0.037 \\
p=0.734\end{array}$ & $\begin{array}{l}r=-0.007 \\
p=0.947\end{array}$ & $\begin{array}{l}\mathrm{r}=0.075 \\
\mathrm{p}=0.488\end{array}$ & $\begin{array}{l}r=-0.068 \\
p=0.524\end{array}$ & $\begin{array}{l}r=0.008 \\
p=0.941\end{array}$ & $\begin{array}{l}r=-0.124 \\
p=0.248\end{array}$ & $\begin{array}{l}r=0.057 \\
p=0.595\end{array}$ & $\begin{array}{l}r=-0.047 \\
p=0.659\end{array}$ & $\begin{array}{l}r=-0.194 \\
p=0.068\end{array}$ & $\begin{array}{l}r=-0.041 \\
p=0.702\end{array}$ & $\begin{array}{l}\mathrm{r}=0.018 \\
\mathrm{p}=0.863\end{array}$ & $\begin{array}{l}r=0.018 \\
p=0.863\end{array}$ \\
\hline General health & $\begin{array}{c}r=0.388 \\
p=0.0001\end{array}$ & $\begin{array}{l}r=0.333 \\
p=0.001\end{array}$ & $\begin{array}{l}r=0.131 \\
p=0.220\end{array}$ & $\begin{array}{l}r=0.358 \\
p=0.001\end{array}$ & $\begin{array}{l}r=0.174 \\
p=0.103\end{array}$ & $\begin{array}{l}r=0.347 \\
p=0.001\end{array}$ & $\begin{array}{l}r=0.120 \\
p=0.262\end{array}$ & $\begin{array}{l}r=0.292 \\
p=0.006\end{array}$ & $\begin{array}{l}r=0.187 \\
p=0.079\end{array}$ & $\begin{array}{l}r=-0.382 \\
p=0.0001\end{array}$ & $\begin{array}{l}r=-0.139 \\
p=0.195\end{array}$ & $\begin{array}{l}r=-0.196 \\
p=0.064\end{array}$ & $\begin{array}{l}r=-0.196 \\
p=0.064\end{array}$ \\
\hline $\begin{array}{l}\text { Total physical } \\
\text { health }\end{array}$ & $\begin{array}{c}r=0.273 \\
p=0.01\end{array}$ & $\begin{array}{l}r=0.212 \\
p=0.047\end{array}$ & $\begin{array}{l}r=0.077 \\
p=0.473\end{array}$ & $\begin{array}{l}r=0.254 \\
p=0.016\end{array}$ & $\begin{array}{l}r=0.054 \\
p=0.613\end{array}$ & $\begin{array}{l}r=0.229 \\
p=0.031\end{array}$ & $\begin{array}{l}r=0.006 \\
p=0.957\end{array}$ & $\begin{array}{l}\mathrm{r}=0.183 \\
\mathrm{p}=0.087\end{array}$ & $\begin{array}{l}r=0.050 \\
p=0.640\end{array}$ & $\begin{array}{l}r=-0304 \\
p=0.004\end{array}$ & $\begin{array}{l}\mathrm{r}=-0.118 \\
\mathrm{p}=0.271\end{array}$ & $\begin{array}{l}r=-0.086 \\
p=0.421\end{array}$ & $\begin{array}{l}\mathrm{r}=-0.086 \\
\mathrm{p}=0.421\end{array}$ \\
\hline $\begin{array}{c}\text { Health } \\
\text { transformation }\end{array}$ & $\begin{array}{l}r=-0.113 \\
p=0.294\end{array}$ & $\begin{array}{l}r=-0.198 \\
p=0.063\end{array}$ & $\begin{array}{l}r=-0.072 \\
p=0.504\end{array}$ & $\begin{array}{l}\mathrm{r}=-0.125 \\
\mathrm{p}=0.242\end{array}$ & $\begin{array}{l}r=-0.094 \\
p=0.381\end{array}$ & $\begin{array}{l}r=-0.150 \\
p=0.160\end{array}$ & $\begin{array}{l}r=-0.089 \\
p=0.409\end{array}$ & $\begin{array}{l}\mathrm{r}=-0.170 \\
\mathrm{p}=0.111\end{array}$ & $\begin{array}{l}r=-0.191 \\
p=0.072\end{array}$ & $\begin{array}{l}r=-0.002 \\
p=0.981\end{array}$ & $\begin{array}{l}r=0.021 \\
p=0.845\end{array}$ & $\begin{array}{l}\mathbf{r}=\mathbf{0 . 2 1 7} \\
\mathbf{p}=\mathbf{0 . 0 4 0}\end{array}$ & $\begin{array}{l}r=0.036 \\
p=0.739\end{array}$ \\
\hline Total SF-36 & $\begin{array}{l}r=0.250 \\
p=0.019\end{array}$ & $\begin{array}{l}r=0.207 \\
p=0.052\end{array}$ & $\begin{array}{l}\mathrm{r}=-0.092 \\
\mathrm{p}=0.390\end{array}$ & $\begin{array}{l}r=0.310 \\
p=0.003\end{array}$ & $\begin{array}{l}r=0.137 \\
p=0.199\end{array}$ & $\begin{array}{l}r=0.271 \\
p=0.010\end{array}$ & $\begin{array}{l}r=0.073 \\
p=0.499\end{array}$ & $\begin{array}{c}\mathrm{r}=0.280 \\
\mathrm{p}=0.08\end{array}$ & $\begin{array}{l}r=0.149 \\
p=0.164\end{array}$ & $\begin{array}{l}r=-0.293 \\
p=0.005\end{array}$ & $\begin{array}{l}\mathrm{r}=-0.107 \\
\mathrm{p}=0.317\end{array}$ & $\begin{array}{l}\mathrm{r}=-0.176 \\
\mathrm{p}=0.098\end{array}$ & $\begin{array}{l}r=-0.045 \\
p=0.678\end{array}$ \\
\hline
\end{tabular}

QOL among hypertensive patients. Measuring and analyzing QOL is complex and when applied to an equally complex medical condition, hypertension, it robust conclusions become evasive. Still, assessment of QOL is important and recent studies suggest that QOL may become an important variable for planning optimal antihypertensive care. Poor QOL may decrease adherence to antihypertensive treatment and it might be prudent to adjust treatment goals individually for optimal QOL $[16,17]$. The results of our study are in agreement with the above studies. Patients with the lowest decrease in systolic blood pressure also had the lowest QOL, while a greater decrease (highest systolic blood pressure in the beginning of the study) of the systolic blood pressure improved QOL most.

According to Hansson et al. (1999) angiotensin receptor blocking drugs did not impair the QOL of hypertensive patients [18]. Dahlof et al. (1997) found losartan better than amlodipin with respect to general well-being [19]. RocaCusaschs et al. (2001) showed that irbesartan combined with other antihypertensive agents improved QOL in patients on continuous antihypertensive therapy [10]. Malmquist et al. (2000) compared candesartan with enalapril or hydrochlorothiazide and found no differences in QOL [5]. In the SCOPE study, patients on candesartan as well as patients in the control group (on placebo) experienced worsening of the QOL [4], but the changes in the parameters describing well-being, health status and anxiety were minor among patients on candesartan. The blood pressure lowering effect of the drug was probably the most important single factor related to QOL improvement in these studies. Also in our study the change in BP, especially the systolic BP, was the single most important factor affecting QOL. Neither candesartan monotherapy nor candesartan combination therapy affected the QOL negatively, when considering the entire patient group, but QOL did decrease in patients on candesartan monotherapy through the whole study.

In a Japanese study dihydropyridine calcium channel blockers were changed to candesartan and it turned out that 
several aspects of QOL improved [20]. In another study, patients mostly on ACE inhibitors and calcium channel blockers with bothersome side effects were changed to valsartan or valsartan in combination with hydrochlorothiazide. There were significant improvements in mean physical and mental scores [21]. In some large hypertension studies (LIFE, VALUE and OnTarget) angiotensin blockers have been better tolerated than the beta blocker atenolol, the calcium antagonist amlodipine and the ACE-inhibitor ramipril [22-24]. We did not compare different medications in our study, but the QOL of patients on combination therapy at the end of the study remained stable or improved compared to monotherapy. The probable explanation for this observation is better hypertension control. For some reason the values of the SF-36 parameters decreased clearly during the last 12 weeks among patients on monotherapy and increased among those on combination therapy (data not shown). From a QOL perspective, our observations support the widely accepted practice of initiation of antihypertensive treatment at a low dose of an antihypertensive drug; if added effect is needed, it is better to add new antihypertensive drugs at low dose than to increase the dose on the first drug to a maximum [8].

In the present study, some patients provided comments in free text on the SF-36 questionnaires and gave various reasons for low scores. Low QOL scores and statistically non-significant findings in the present study may have partly resulted from interfering elements not associated at all with the antihypertensive treatment. Such elements could be other diseases and family problems, as implied by the comments of the participants. These observations underline that the SF36 method is very selective and is susceptible to random factors that may influence the treatment being studied. Thus, reliable clinical conclusions may be difficult to draw on the basis of the present SF-36 data. In this respect we share the opinion of Degl'Innocenti et al. [4]. We also observed lack of motivation and carefulness in the filling of the SF-36 forms.

\section{CONCLUSION}

Candesartan, even at a low dose, reduces blood pressure effectively. This study showed no statistically significant change in QOL in spite of an adequate BP decrease among the patients who used candesartan monotherapy throughout the study. The most significant variable associated with increased QOL was the amount of systolic blood pressure reduction during the study. Thus, our study underlines the importance of an adequate antihypertensive effect as one of the main QOL-related variables among patients being treated for high blood pressure. QOL is not increased if angiotensin receptor antagonist treatment is administered alone without an adequate reduction in blood pressure.

\section{CONFLICT OF INTEREST}

The authors confirm that this article content has no conflict of interest.

\section{ACKNOWLEDGEMENTS}

\section{REFERENCES}

[1] Tarlov AR, Ware JE Jr., Greenfield S, et al. The Medical Outcomes Study. An application of methods for monitoring the results of medical care. JAMA 1989; 262: 925-30.

[2] Hagman E. SF-36 terveyskysely koetun terveyden ja toimintakyvyn mittarina. Suom Lääkäril 1996; 51: 3534-9.

[3] Saastamoinen P, Leino-Arjas P, Laaksonen M, et al. Pain and health related functioning among employees. J Epidemiol Community Health 2006; 60: 793-8.

[4] Degl'Innocenti A, Elmfeldt D, Hofman A, et al. Health-related quality of life during treatment of elderly patients with hypertension: results from the Study on Cognition and Prognosis in the Elderly (SCOPE). J Hum Hypertens 2004; 18: 239-45.

[5] Malmquist K, Kahan T, Dahl M. Angiotensin II type 1 (AT1) receptor blockade in hypertensive women: benefits of candesartan cilextil versus enalapril or hydrochlorothiazide. Am J Hypertens 2000; 13: 504-11.

[6] Law MR, Wald JN, Morris JK, et al. Value of low dose combination treatment with blood pressure lowering drugs: analysis of 354 randomised trials. BMJ 2003; 326: 1427-34.

[7] Niiranen TJ, Kantola IM, Vesalainen R, et al. A comparison of home measurement and ambulatory monitoring of blood pressure in the adjustment of antihypertensive treatment. Am J Hypertens 2006; 19: 468-74.

[8] Mancia G, De Backer G, Dominiczak A, et al. 2007 ESH-ESC Guidelines for the management of arterial hypertension: the task force for the management of arterial hypertension of the European Society of Hypertension (ESH) and of the European Society of Cardiology (ESC). Blood Press 2007; 16: 135-232.

[9] Battersby C, Hartley K, Fletcher AE, et al. Quality of life in treated hypertension: a case controlled community study. J Hum Hypertens 1995; 9: 981-6.

[10] Roca-Cusachs A, Dalfó A, Badia X, et al. Relation between clinical and therapeutic variables and quality of life in hypertension. $\mathrm{J}$ Hypertens 2001; 19: 1913-9.

[11] Wiklund I, Halling K, Ryden-Bergsten T. What is the effect of lowering the arterial blood pressure on the quality of life? An auxiliary study to the HOT (Hypertension Optimal Treatment) trial. Arch Mal Coeur Vaiss 1999; 92: 1079-82.

[12] Fletcher A. Quality of life in the management of hypertension. Clin Exp Hypertens 1999; 21: 961-72.

[13] Kaplan N, Norman M. Kaplan's Clinical Hypertension. Baltimore, USA: Lippincott Williams \& Wilkins (LWW) 1998.

[14] Bremner AD. Antihypertensive medication and quality of life silent treatment of a silent killer? Cardiovasc Drugs Ther 2002; 16: 353-64.

[15] Lambert G, Hering D, Esler M, et al. Health-related quality of life after renal denervation in patients with treatment-resistant hypertension. Hypertension 2012; 60: 1479-84.

[16] Zygmuntowicz M, Owczarek A, Elibol A, et al. Blood pressure for optimal health-rated quality of life in hypertensive patients. J Hypertens 2013; 31: 830-9.

[17] Trevisol D, Moreira L, Fuchs F, et al. Health-related quality of life is worse in individuals with hypertension under drug treatment: results of population-based study. J Hum Hypertens 2012; 26: 37480.

[18] Hansson L, Lindholm LH, Niskanen L, et al. Effect of angiotensinconverting-enzyme inhibition compared with conventional therapy on cardiovascular morbidity and mortality in hypertension: the Captopril Prevention Project (CAPP) randomized trial. Lancet 1999; 353: 611-61.

[19] Dahlof B, Lindholm LH, Carney S, et al. The LOA Study group. Main results of the losartan versus amlodipine (LOA) study on drug tolerability and psychological general well-being. J Hypertens 1997; 15: 1327-35.

[20] Yamamoto S, Kawashima T, Kunitake T, et al. The effects of replacing dihydropyridine calcium-channel blockers with angiotensin II receptor blocker on the quality of life of hypertensive patients. Blood Press Suppl 2003; 2: 22-8.

Goodman R, Lanese J, Singson C, et al. Symptom assessment and quality of life in hypertensive patients following modification of antihypertensive therapy to a regimen containing valsartan. J Clin Outcomes Res 2004; 8: 1-14. 
[22] Dahlöf B, Devereux RB, Kjeldsen SE, et al. Cardiovascular morbidity and mortality in the losartan intervention for endpoint reduction in hypertension study (LIFE): a randomised trial against atenolol. Lancet 2002; 359: 995-1003.

[23] Julius S, Kjeldsen S, Weber M, et al. Outcomes in hypertensive patients at high cardiovascular risk treated with regimens based on valsartan or amlodipine: the VALUE randomised trial. Lancet 2004; 363: 2022-31.

[24] The ONTARGET Investigators. Telmisartan, ramipril, or both in patients at high risk for vascular events. N Engl J Med 2008; 358: 1547-59.

(C) Varis et al.; Licensee Bentham Open.

This is an open access article licensed under the terms of the Creative Commons Attribution Non-Commercial License (http://creativecommons.org/licenses/by$\mathrm{nc} / 3.0 /$ ) which permits unrestricted, non-commercial use, distribution and reproduction in any medium, provided the work is properly cited. 